\title{
Perception of Environmental Change Relationship to Labor Migration in the Chitwan Valley
}

\author{
Jessica Miller \\ Grad Student, The Graduate Center, City University of New York, USA \\ jmiller5@cuny.gradcenter.edu
}

\begin{abstract}
This research examines environmental change, in terms of agriculture production, influence on outmigration from the Chitwan Valley in Nepal. As the first part of a longitudinal study, a maximum variation sampling method was used to gather data on farming households' perceptions of environmental change and labor migration. While collecting field data, verbal consent was obtained from research participants and their identities protected. This study uses the measures of environmental change, social capital, and environmental history to analyze risk formation and amplification along migrant networks. Additionally, using t-tests, this data was compared to a sample from the Chitwan Valley Family Study (CVFS) to observe change in perception and labor migration over time. The analysis concludes that perception of environmental change interacts with socio-cultural processes in ways that intensify household level migration. In addition, environmental change is one of the main factors causing low efficiency in agriculture production, leading households to diversify occupation and income through labor migration.
\end{abstract}

Keywords: Labor Migration, Agro-meteorology, Environmental Change, Agriculture

\section{Introduction}

According to the Intergovernmental Panel on Climate Change (IPCC), South Asia has experienced increased temperatures and variability in rainfall that have affected agriculture production, food scarcity, and water resources (IPCC, 2015). In agriculturebased societies such as Nepal, crop production depends on consistent patterns of rainfall and temperature. These trends and vulnerabilities are predicted to continue for the coming decades and lead to increases in labor migration (Climate \& Development Knowledge Network, 2014) .

Environmental factors play a significant role in shaping the decision to migrate. Previous research has hypothesized that perceived changes in land productivity will lead to increased labor migration along already established migrant networks in order to achieve greater socioeconomic prosperity (Bardsley, 2010; Bohra, 2009, Massey, 1993; Shrestha, 2007). Specifically, perceived decreases in agricultural production is found to be a predictor of international and local movement of populations (Massey, 2010). At the local level, communities and individuals determine whether an environmental change is acceptable or problematic, and adjust accordingly, usually in the form of an adaptation mechanism, such as migration (Bardsley, 2010; Kasperson, 1988). To explore how risk communication process at the household and community level determine whether an environmental change is acceptable or problematic, this research uses the Social Amplification of Risk Framework to analyze the role a migrant's extended network plays in their perception of environmental risk. The measures of environmental change, defined as change in agriculture production over the past three years, environmental history, defined as the amount of crop loss and moves due to flood and/or drought a farming household has incurred over a lifetime, and social capital, defined as a farming household with a family member who has migrated internationally and participated in environmental program or campaign, are 
employed to better understand environmental risk formation.

Due to the fact that perceived decrease in land productivity is likely to be a strong motivator for migration along established networks (Massey, 2010), this research argues that informal social networks amplify environmental risk communication resulting in the household response to migrate. Additionally, socio-cultural factors of gender, age, and ethnicity influence the risk perceived from environmental change.

This research utilizes household data to observe the connection between perceptions of environmental change and the motivation to migrate. Using a maximum variation sampling method, this study employs a quantitative survey and semi-structured interviews to gather data on agriculture production and labor migration. Additionally, household level data collected through the Chitwan Valley Family Study, consisting of qualitative interviews and household survey data collected over a fifteenyear period, is used to observe a change over time in perceptions of agriculture production and labor migration (Axinn, 2011; Barber, 2003; Bohra, 2009; Ghimire, 2018; Massey, 2010).

The quantitative survey covers four areas main areas involve in environmental change and labor migration. The topics discussed are environmental history, perception of agriculture production, access to natural resources, labor migration and interaction with environmental campaigns or programs. The overall goal of this research is to understand, in terms of environmental change, the role threat perception plays in the decision to migrate. Specifically, this research seeks to understand what community, historical, and environmental factors make up or contribute to a migrant's perception of risk.

\section{Location}

This fieldwork was conducted in Nepal's Chitwan district, a largely agriculture-dependent society with a fragile ecosystem (Massey, 2010). Due to Chitwan farmers' reliance on intensive crop rotation for sustenance and income generation, Nepal's Chitwan district is the ideal setting to observe a potential link between environmental change and out-migration (Barber, 2003; Bardsley, 2010; Ghimire, 2018; Massey, 2010).

The Chitwan region of Nepal has a long history of labor migration, both to and from the region. Due to waves of migration from India and Tibet, Nepalese society is comprised of more than 60 ethnic/caste and linguistic subgroups. For a century, population mobility in Nepal had stalled and the Terai region was considered uninhabitable (Massey, 2010; Shrestha, 2007). However, in the 1950s, Nepal initiated policies that encouraged migration from the mid-hill region to the Terai, the flat low-lying plains. Government policies provided land grants to officers through a land reclamation and resettlement program that was focused on the eradication of malaria (Sijapati, 1981). As one of the target locations, this program created a more diversified ethnic composition in the Chitwan (Massey, 2010).

\section{Framework}

According to the Social Amplification of Risk framework, posited by Roger E. Kasperson, hazards, such as an environmental change interacts with the psychological, social, institutional, and cultural processes in ways that may intensify or reduce public response to a risk or related risk behavior, such as migration (Godwin, 1997; Kasperson, 1988; Miker, 1977). Relying heavily on communication theory, it describes the amplification of risk as a signal in an information system that initiates as a risk event triggering an individual and community response. After the initial flow of information, there is risk-related behavior that involves an interpretation and response by social groups or individuals that can trigger a third spread of impact (Kasperson, 1988).

Drawing on Kasperson's work, Sanders Van Linden formulated a social-psychological model of climate change risk that tests for cognitive, social-cultural, and experiential processing as factors that influence risk perception. According to Linden's Climate Change Risk Model, sociodemographic characteristics had an influence over an individual's risk perception. Linden's work found that political affiliation, gender, social norms, and previous experience influences climate change risk perception (Van der Linden, 2017). In a London sample size, he controlled for socio-demographic characteristics and found a 70 percent variation in climate change risk perceptions among respondents. Van Linden's research emphasizes the importance of sociocultural factors and local weather as factors that influence risk perception (Van der Linden, 2017). 
Risk is a formation of human construct; therefore, there is great cross-cultural variation between socio-cultural and economic context (Gardner, 1981; Van der Linden, 2017; Weber, 2010; Wildavsky, 1990). Both Van Linden's and Kasperson's risk perception models were applied to research samples in developed European states, where agriculture is not the main source of livelihood (Howe, 2015; Hsee, 2001; Joffe, 2003). There is a lack of risk perception research focused in developing states, such as Nepal with agriculture dependent economies, as well as on social networks influence on risk perception. This research applies Kasperson's framework to migration. In this analysis, environmental change as a risk event, interacts with socio-cultural factors causing the intensified risk response of migration. The continued applied hazard of long term environmental change will lead to selfperpetuating migration along informal social networks. Factors that influence the household response of migration is transnational, such as existing in both receiving and sending countries.

Kasperson's framework includes informal social networks as a channel of amplification; however, the impact of personal and social networks is not quantifiably. Kasperson's framework is not applied to a risk event occurring gradually over a long period of time, such as climate change. This research quantifies Kasperson's theoretical framework of risk perception and Lindens application to climate change through multivariate analyses in SPSS analyzing the relationship between labor migration and perception of agriculture production. Additionally, t-tests compare household level data, collected through the Chitwan Valley Family Study, to observe a potential change over time in perceptions of agriculture production and labor migration.

\section{Literature review}

\section{Theories of Migration}

Four theories of migration: Neoclassical; New Economics of Labor Migration; Social Capital; and Cumulative Causation, play into the factors that drive labor migration in the Chitwan Valley (Massey, 2004). The Neoclassical Economic Model of Labor Migration postulates that migration is a response to imbalances in the spatial distribution of land, capital, and labor. Therefore, human capital flows from areas with an abundance of labor and scarce capital to areas where the inverse is present (Ali, 2015; Massey, 2005; Massey, 2015; Stahl, 1995). Moreover, this model assumes a destination has been selected based on an individual's rational economic response to maximize their future economic income. Like the Neoclassical Model, the New Economic Theory of Labor Migration posits that labor migration is caused due to an imbalance in the labor market (Massey, 2005; Massey, 2015, Stahl, 1995). However, rather than being driven by an imperfect market in land, labor, and capital, migration is driven by geographical wage differences. Moreover, this theory views the decision to migrate as a collective household process, instead of an individual decision.

The Neoclassical and New Economics of Labor Migration theories have been widely criticized for ignoring historical labor flows, social-cultural context, and predicted equilibrium conditions (Massey, 2004). While the neoclassical and new economics of labor migration models focus on the economic reasoning for migration, they lack the anaylsis of sociocultural factors that play into the household decision-making process. Originally posited by Glenn Loury and expanded by Pierre Bourdieu, Social-Capital Theory, or Network Theory, states that the transnational movement of people from one place to another for work form social ties that connect their host and receiving communities. These ties provide a source of social capital in the form of information, resources, and assistance, that lower the costs of migration. The social capital created when a person migrates can be used by that migrant's entire host community (Massey, 1995, 2004). The continual creation of social capital overtime forms a self-perpetuating process known as Cumulative Causation (Massey, 1995; Poros, 2010, 2011), where by migration becomes easier and the financial burden decreases.

Due to a lower financial burden, second generation migrants perceive a reduced risk from out-migration as opposed to the previous generation (Massey, 2004). In the Chitwan Valley, environmental change is a cause of decreases in agricultural production that has led to lower economic output and increased risk to enter agriculture as an occupation (Axinn, 2017; Ortiz, 2012; Shrestha, 2007, 2011; Smith, 2017). First, authors Dirgha J. Ghimre, William G. Axinn, and Prem Bhandari analyzed the effect of labor migration on the likelihood of exiting farming. Using multilevel dynamic models to estimate the 
effect of out-migration and remittance on the exit from agriculture in the Chitwan Valley, they find that duel risk factors exist. The authors conclude that the loss of farm labor to international labor migration increases the likelihood to exit farming among households that remain. Conversely, they find that amount remittance decreases the possibility that a household will exit farming (Ghimire, Axinn, \& Bhandari, 2018).

Furthermore, using data from the Chitwan Valley Family Study, authors Massey and Bohra find strong support for Social Capital theory as a predictor for individual migration. They conclude that neighbors with international experience abroad increases the likelihood of individual migration and find the theory of cumulative causation a major predictor of individuals migrating internationally for a second trip, which was location specific (Bohra, 2010). Also, ethnicity played a role in the location of a migrants first trip and preceding trips (Barber, 2011; Bohra, 2010).

This research uses Social Capital theory to analyze the transnational flows of information through the lens of Kaperson's risk framework. Communication of environmental risk, such as changes in agriculture production, is amplified via the transnational flow of information along migrant networks. Along with traditional migrant networks of family members, neighbors and local leaders, informal networks, such as community programs, and education abroad will amplify or reduce risk from environmental change. This research predicts that extended education and employments networks outside of agriculture will become an important vehicle for migration as environmental change is perceived to affect income generation through declines in crop production and the inability to gather or purchase natural resources.

\section{Environmental Change in Nepal}

Nepal is predominantly an agriculture-based society, in which agriculture production has an inverse relationship to labor migration (Satyal, 2010). According to Nepal's Department of Agriculture, $65.7 \%$ of the population relies on agriculture production as their main source of livelihood; however, agriculture production only makes up $30 \%$ of the National Gross Domestic Product (GDP) (Ministry of Agriculture Development, 2015). Since 1970, the portion of GDP derived from agricultural production shrunk from $69 \%$ in $1974-1975$ to $31 \%$ in 2009 2010 (Economic Survey, 2010). On the other hand, international labor migration has accelerated since the Foreign Employment Act of 1985, and rapidly increased since the end of the civil war in 2006 (Satyal, 2010).

According to the World Bank, approximately $31.3 \%$ of Nepal's GDP comes from remittance flows from Nepali migrants abroad (World Bank, 2017). The Foreign Employment Act of 1985 liberalized the foreign employment process and encouraged low-skill labor migration to Gulf countries. Due to the oil boom that began in the 1970s, there was increased job availability in the service and construction sectors. This act opened avenues for private sector actors, such as recruiters, to facilitate foreign employment (Massey, 2004; Sijapati, 1981).

Previous research conducted in the Chitwan Valley finds an indirect relationship between environment change and migration (Axinn, 2018; Barber, 2011; Massey, 2010; Shrestha, 2007). Conducted through the Chitwan Valley Family Study (CVFS), previous research focused on consumption, increasing population density, and factors of environmental degradation. Authors Douglas S. Massey, William G. Axinn, and Dirgha J. Ghimire tested for factors of neighborhood population density, perceptions of agricultural production, time required to collect firewood and gather fodder, and the share of neighborhood covered with flora to measure the impact on migratory behavior. They concluded that only perceived agrarian productivity, the share of neighborhood covered in flora, and the time required to collect firewood influences mobility. Individuals were more likely to look for work elsewhere in the valley, rather than emigrate internationally. Additionally, they found that environmental migration is related to both environmental calamities, as well as gradual deterioration of conditions (Massey, 2010). This research utilizes and expands on factors tested for in the CVFS. To analyze risk formation of environmental change, this research tests for of perception of agriculture production, household consumption and labor migration. The results of this study are compared to the data collected through Massey's, Axinn's, and Ghimire's study on environmental degradation to observe change in perception and labor migration over time.

In addition, authors Jennifer S. Barber, Ann E. Biddlecom, and William G. Axinn added to this research in a three-year study on the perception 
of environmental degradation's connection to social change in the Chitwan Valley. They found an association between an increase in neighborhood facilities and perceived environmental degradation. Increasing neighborhood facilities were found to be associated with perceptions of environmental degradation. They concluded that environmental degradation is likely to encourage participation in environmental programs and influence behaviors, such as migration (Barber, 2011). Barber, Biddlecom, and Axinn identify a need for further research to better understand what shapes perceptions of environmental degradation, as well as additional measures of environmental degradation and behaviors related to the environment.

This research adds to a body of work on environmental change and migration by analyzing risk formation. In addition to testing for perception of agriculture production and labor migration, this work tests for the factors of knowledge of and participation in environmental programs or campaigns, as well as for crop loss and household moves due to flood and drought. Households interaction with the environment can shape formation of risk (Hunter, 2005), therefore, by combining these four factors, along with testing for demographic and consumption data, this research seeks to understand how risk formation of agriculture production may influence labor migration.

\section{Methodology}

Field work was conducted in the Chitwan Valley, in the south-central part of Nepal, as the first part of a mix-method longitudinal study examining the relationship of risk perception of agricultural production and out-migration. In a one-month period, 107 household surveys and 12 semi-structured interviews were conducted in twenty-three villages in nine towns. Ten interviews were conducted with farming households in the research area and two were conducted with organizations involved in environmental focused programs.

The Chitwan Valley was chosen as a field location due to the high percentage of households involved in farming and the availability to study the change in household perception of environmental change overtime through the Chitwan Valley Family Study (CVFS). The CVFS is used as a baseline comparison in the analysis. As part of the CVFS, household level agricultural and migration data was collected in 1996, 2001, and 2015. This study collected data on agriculture productivity, labor migration, and food security. Data was collected within 171 neighborhoods defined as 5-15 households. A total of 2,361 households were survey in 1996 with a response rate of $98.1 \%$. It encouraged multiple household member participation, in which more than onethird of the interviews have documented. Around one-half of the research participants surveyed were female and the average age of the primary respondent was 42 . The CVFS on agriculture and consumption conducted in 1996 gather information on farming; such as farming versus non-farming household, land holdings, and farm practices; livestock, such as collection of fodder, amount and type of livestock; household items, such as ownership of a tractor, gobar (animal dung) gas plant, and transportation; perceptions of environmental change, such as changes in the water level, changes in agricultural production, and changes in time to collect fodder; and migration, such as amount and location of members living away and remittance (Axinn, 2006; Barber, 2003; Bhandari, 2016; Massey, 2004).

This questionnaire expands on two areas within the CVFS's agriculture and consumption survey. Using the underlying theories of migration and risk formation to examine the relationship between environmental change and labor migration, the questionnaire was comprised of eight sections divided into demographic data, agricultural data, livestock, household items, change in agriculture production, personal experience, and environmental program participation. The data controlled for demographic factors, such as age, ethnicity and gender. The perception of environmental change section of the questionnaire gathered information on agricultural productivity over the last three years, water table levels, and use of chemical fertilizer. This information was gathered to analyze the relationship between a migrant's network and perception of agricultural production over time.

Using a maximum variation sampling method, nine neighborhoods, defined as five to fifteen households, were chosen to distribute the questionnaire. These neighborhoods were selected with the assistance of a research coordinator and translator withlocal knowledge of Chitwan to achieve a variation in socio-economic levels within the sample. While gathering field 
data, verbal consent was obtained from research participants and their identities protected. The questionnaires and interviews were carried out in Nepali and communication with participants occurred using a translator. In communities with a low literate population the questionnaire was read verbally, word for word to the respondent and their response was transcribed in Nepali and later translated to English. Acknowledging the small sample size in the first part of this study, this method was chosen to obtain an accurate portion of the population.

\section{Analytical strategy}

First, descriptive and bi-variate tests were run to explore the correlations within the measures of environmental change, social capital, and environmental history. Then, ANOVA or ChiSquare test were used as appropriate between each measure. Multi-response analyses were used to explore the relationship between labor migration and perception of agriculture production. Furthermore, t-tests were used to compare household level data collected in 1996 with the data collected through this study to observe a potential change over time in perceptions of agriculture production.

\section{Measurements}

Through this analysis the goal is to better understand risk perception of environmental change, its formation, and relationship to labor migration. The following measure were developed to study this relationship:

Measures of environmental change are defined as change in agricultural productivity; several factors which influence productivity were tested for in the questionnaire. Three-year perceived change in amount of use of chemical fertilizers, water table levels, and agriculture production were each tested for. A perceived increase in the amount of chemical fertilizer was given a code of 3 , decrease 1 , and no change 2 . If the respondent did not know, it was coded as 0 . Respondents were asked, "was there was a change in water table levels in your or your neighbor's wells?” For this question yes was coded as 1 and no as 0 . Lastly, a perceived change in agriculture production was coded as 1 for increased, 2 for decrease, and 0 for no change. After running descriptive tests on each variable, ANOVA or Chi-Square test was run to test the relationship between variables.
After establishing a change, increase or decrease, respondents were asked to give a reason of the change in production. Each question was coded in a multiple response set and value set to 1 .

Measures of social capital: In this anaylsis, a migrant's extend network is examined to understand environmental communication over informal networks relationship to risk perception. Social capital was defined as a farming household with a family member who has migrated internationally and participated in an environmental program or campaign. Respondents were asked, "Have you or your family member migrated internationally or domestically for work?" If the respondent reported an international migration, it was coded as 1 , and domestic migration was coded as 0 . Additionally, respondents were asked "Have you or a family member participated in any environmental programs or campaigns?" If yes, it was coded as 1 and no was coded as 0 . These variables were tested in a multivariate correlation against household characteristics and measurements of environmental change.

Measures of Environmental History: Environmental History was defined as the amount of crop loss and moves due to flood and drought a farming household has incurred over a lifetime. It is hypothesized that respondents who have incurred a larger amount of crop loss and moves in their lifetime will perceive decrease in agriculture production. If a household had incurred a move due to a drought it was coded as 1 ; if not, it was coded as 0 . Similarly, if a household has incurred a move due to flood it was coded as 1 ; if not, it was coded as 0 . Additionally, households were asked separately if they had incurred crop loss due to drought and crop loss due to flood. If a respondent reported a crop loss it was coded as 1 ; if not, it was coded as 0 .

Measure of Household Characteristics (gender, age, caste, plots of land, pump set, etc.): Household characteristic were tested against measures of perception and migration to see if there were any differences in the way household perceived changes, as well as the social capital they held. Pervious research conducted in the Chitwan Valley suggest that High caste hold more social capital that other castes. Additionally, age, gender, and ethnicity influence environmental risk perception; 
therefore producing different responses to the same risk event. Crosstab analysis were used to analyze correlations and frequency between these measures.

\section{Descriptives}

\section{Demographic Data}

Descriptive and frequency tests ran on the sample size of 107 can be found in table 1 and table 2. The research participants consisted of a total of 102 farming household and 5 nonfarming household (outliers). 50 or $46.7 \%$ of the respondents were female and 53 or $49.5 \%$ were male. The analysis classified caste into five categories of High caste Hindu, Hill TibetoBurmese and Buddhist, Indigenous Tarai TibetoBurmese, Newar, and other caste Hindus. The respondents identified as 53.3\%, 14\%, 6.5\%, 2.8\% and $9.3 \%$, respectively. The means and standard deviations used in analyses can be found in table 1 . The mean age of the sample was 44.24 and the ages ranged from 19-81. This research used a wield age range to capture a diverse range of environmental perceptions. The average household size of a response was 5 people.

\section{Results}

Of the respondents, $71 \%$ perceived a change in agriculture production. $38.3 \%$ perceived a decrease in production and $32.7 \%$ perceived an increase. Table 1 displays the means and standard deviations for respondent's perception of environmental change used in analyses.

One-sample t-tests were conducted, with the variables difference in water table levels, international labor migration, changes in agriculture production, and change in use of the amount of chemical fertilizer. The results can be found in table 3 . There was no significant difference between the two means of change in agriculture production and changes in use of chemical fertilizer; however, there was a significant change in the means of water table levels and international labor migration. Each displayed a positive critical value of 1.66 . and households with a migrant increase from $29.1 \%$ to $55.7 \%$.

A multi-response analysis for household crop cultivation showed that most households are currently cultivating red lentils. The survey asked respondent "what crops do you cultivate" to examine the relationship between the type of crops being cultivated and perception of environmental change. Respondents reported $26.8 \%$ were cultivating red lentils, $11.3 \%$ potatoes, $12.4 \%$ wheat, $18.0 \%$ mustard, $1.5 \%$ barley, $4.1 \%$ Paddy 1.5 oil seed, $5.2 \%$ corn, $9.8 \%$ peas, 1.0 corn, $8.8 \%$ other vegetables, and $0.5 \%$ fruits. An independent t-test of households that grow red lentils showed a significant difference between those that perceive a decrease verse increase in agriculture production. Respondents who both cultivated red lentils and perceived agriculture to be decreasing believe it was due to insects and disease. Moreover, respondents who perceive an increase and cultivated red lentils are likely to do so due to the use of new crop varieties.

\section{Environmental History}

A chi-square test showed a significant relationship between households that incurred a crop loss due to flood and perception of agriculture production at a .032 significance value. 17.5 percent of households that had incurred a crop loss due to flood were more likely to perceive a decline in agriculture production. Additionally, the results of a chi-square test showed households that experienced crop loss due to drought are more likely to have experienced crop loss due to flood at a significance value of .024. Also, households that have incurred a move to due to a flood are more likely to have incurred a crop loss due to flood.

This corresponds to interviews and observations with farming households that conclude communities that lie along rivers and floodplains are more vulnerable to crop loss and moves to weather events, such as flood and drought. Households that perceive a decrease in agricultural production note bad irrigation, or the lack of an irrigation facility, which the majority, $23.3 \%$ select as the reason for agricultural decline. All interview respondent state that monsoon arrival is erratic; however, no households is changing the time they sow their seeds to "accommodate the arrival of rain." Half of the interview participants report damage to mustard and red lentils due to the late arrival of monsoon last rain season. Many households without irrigation facilities report between one-fourth to one-half loss in yield depending on the crop. Additionally, interview participants that perceive an increase state it is due to the use of chemical fertilizer. Participants 
have significantly lower yields without the uses of chemical fertilizer; however, using it causes a depletion of nutrient from the soil and more is needed after every use.

There is a positive correlation between not having an irrigation facility and crop loss due to drought. Respondents who irrigated their crops with a canal only were more likely to incur a crop loss due to drought. The results of a chi-square test showed .025 significance between type of irrigation and perception of agriculture change. Respondents who irrigate crops with a canal only were around twice as likely to perceive a decrease than those who do not.

\section{Social Capital}

All ten interviewed farm households reported increases in labor migration within their communities over the past three years. Within 107 household surveys, 55.1\% contain a current or returned labor migrant. Of those $60.2 \%$ had migrated international and $30.8 \%$ domestically. Most households selected unemployment as their main reason for migrating. Following unemployment, $11.5 \%$ of respondents reported increased debt, 8.9\% low income from agricultural, $4.9 \%$ low agriculture income, $4.9 \%$ improved neighborhood livelihoods, and 3.3\% reported an increase in family size as their main reason for migration.

In terms of social capital, defined as international labor migration and participation in environmental programs or campaigns, High castes, such as Brahmin and Kshyatriya, have higher amounts of social capital measured by case. The results of a chi-square test with .016 significance showed that respondents that participate in a program are likely to perceive no change in agricultural production. Moreover, there was a negative correlation between respondents that migrated internationally and participated in a program or campaign. Thus, respondents that migrated internationally are less likely to participate in a community development or environmental program.

Additionally, most interview participants reported an inverse relationship between labor migration and agricultural production over the past three years. Due to low yields from drought and declines in market value, agriculture income has been steadily decreasing. Respondents whose family had been farming for generation report theirs is the first to migrate for work. There is not enough financial return in agriculture production to sustain a household. Some households held multiple jobs, and some were exiting agriculture.

\section{Conclusion}

\section{Exit from Agriculture}

In conclusion, the risk of environmental change interacts with psychological, social, institutional, and cultural processes in ways that intensify household level migration. The analysis showed low efficiency in agriculture production leads households to diversify occupation and income through migration to mitigate risk from decreases in agriculture production. Unemployment driven migration is the result of low income from agriculture production. Over the past couple of decades, there has been a growing increase in the gap between households that were active in agriculture and those that claim agriculture as their main occupation. This number grew from 19 thousand in 1991 to 641 thousand in 2001. Vikasn Raj Satyal classifies these households as "farmers by birth but having alternative occupation for livelihood.” The research finds first generation migrants in households who have been farming for generations.

A culture of migration is created through the accumulation of social capital, which lessens the financial burden of migration, making the process less of a risk than going into agriculture. This is evident from the large increase in labor migration since the 1996 CVFS and consistent perception of agriculture production. Children of first generation labor migrants are not entering agriculture, but rather going into other occupations abroad, such as construction and service sector jobs. While unemployment is cited as the main reason for labor migration, through interviews and observations, unemployment appears to identify a second-generation migrant not able to find employment outside of agriculture within Nepal. Due to fluctuating market price and erratic monsoons causing decreases in yield and intern low farm income, job diversification through labor migration reduces risk from agriculture production.

\section{Formations of Risk}

Household risk perception is influenced by environmental history and interaction 
with agriculture. Crop loss and moves due to weather events, international migration, and demographic factors all effect the way households perceive risk. Because international migration decreases the financial burden from agriculture, households with family members abroad are less likely to perceive a risk from a change in production. The transnational movement of information, people, and capital via the process of migration leads to a disconnect with the local community; and therefore, less investment in community development and participation in programs, such as environmental awareness or clean up.

International migration lessens the risk from agricultural production by decreasing the financial burden and causing a disengagement with agriculture. Some households, largely those from High castes who have greater amounts of social capital to migrate to Europe, Australia, and the United States, can hire labor, pay off debt, and some exit agriculture completely. All avenues lessen household's interaction with agriculture production and the ability to perceive a change or risk from it.

Like pervious research, this study finds high castes and low castes were more likely to perceive a risk from a decrease in agricultural production. In lower castes, this is believed to stem from less access to social capital and therefore households are more likely to have a greater interaction with agriculture. Households from low castes are less likely to have hired labor, migrated abroad, and are more vulnerable to abrupt changes in weather or long protracted droughts that cause a greater amount of crops loss and moves. Conversely, within high castes, females perceive more of an increase in production compared to men. This is likely due to the increase in the feminization of agriculture labor in Nepal (Gartaula, 2012). Direct male interaction with the agriculture process has decrease due to the increase in international labor migration. Women have taken over traditional male roles, such as going to the market, working in the field, applying chemical fertilizer, and others.

\section{Environmental Communication}

This research finds that transnational migration networks reduce the risk from environmental change, while local informal networks amplify environmental risk. Environmental risk communication travels along local social networks, such as community development programs. The most common form of program participation is a community development program formed by the local village and is run by a village council. Households with less social capital, who have participated in a program and not migrated, are more likely to perceive change in production. Conversely, households with a labor migrant and with one or more member that has participated in an environmental program, were likely to perceive no change in agriculture production. International labor migration reduces the risk from change in agriculture production. Due to income diversification and disconnect from agricultural activity, environmental risk was reduced, rather than amplified.

Further research is needed to better understand environmental communication along transnational networks. This research did not focus on aspects of weather; however, research has shown individuals and households can perceive weather as climate. It can influence household opinion on environmental change and is worth further observation. In addition to further research on measures of risk formation, exploration of international migration and the disconnect or exit from agriculture's connection to migration will add to a growing body of research on environmental change and migration.

\section{References}

Ali, S., \& Hartmann, D. (2015). Migration, incorporation, and change in an interconnected world. New York: Routledge.

Axinn, W.G. \& Pearce, L.D. (2006). Mixed method data collection strategies. New York: Cambridge University Press.

Axinn, W.G. (2015). Demographic change: The case of chitwan valley in Nepal.” International Journal of Sociology, 45(1):1-3. 
Axinn, W.G. \& Ghimire, D.J. (2011). Social Organization, Population and Land Use. American Journal of Sociology, 117(1):209-258.

Barber, J. S., Biddlecom, A. E., \& Axinn, W. G. (2003, 11). Neighborhood Social Change and Perceptions of Environmental Degradation. Population and Environment, 25(2), 77-108. doi:10.1023/ b:poen.0000015559.53819.ab

Bardsley, D. K., \& Hugo, G. J. (2010, 09). Migration and climate change: Examining thresholds of change to guide effective adaptation decision-making. Population and Environment, 32(2-3), 238262. doi:10.1007/s11111-010-0126-9

Bhandari, P.B. and Ghimire, D.J. (2016). Rural Agricultural Change and Individual Outmigration. Rural Sociology 81(4): 572-600.

Bohra, P., \& Massey, D. S. (2009, 09). Processes of Internal and International Migration from Chitwan, Nepal. International Migration Review, 43(3), 621-651. doi:10.1111/j.1747-7379.2009.00779.x

Brusle, T. (2008, Aug-Nov). Choosing a Destination and Work: Migration Strategies of Nepalese Workers in Uttarakhand, Northern India. Mountain Research and Development, 28(3-4), 240-247.

Climate \& Development Knowledge Network. (2014). The IPCC's Ffth Assessment Report: What's in it foor South Asia? Genva: Intergovernmental Panal on Climate Change.

Gardner, R. W. (1981). Macrolevel Influences on the Migration Decision Process. In De Jong G.F \& Gardner, R.W. (EDs) Migration decision making: multidisciplinary approaches to microlevel studies in developed and developing countries (59-89).New York: Pergamon

Ghimire, D. J., Axinn, W. G., \& Bhandari, P. (2018). Social Change, Out-Migration and Exit from Agriculture (07-615) Retreived from University of Michigan, Institute of Social Research. Ann Arbor: Population Studies Center https://www.psc.isr.umich.edu/pubs/pdf/rr07-615.pdf

Hsee, C. K., Loewenstein, G. F., Weber, E. U., \& Welch, N. (2001). Risk as Feelings. American Psychological Association , 127(2), 267-286.

Karki, Y. K. (2015). Nepal Portfolio Performance Review. Kathmandu: Ministry of Agriculture Development.

Krause, U. (2017). Researching forced migration: critical reflections on research ethics during fieldwork. University of Oxford, Oxford Department of International Development . Oxford: Refugee Studies Centre.

Massey, D. S., Arango, J., Hugo, G., Kouaouci, A., Peliegrino, A., \& Taylor, E. J. (1995). Theories of International Migration: A Review and Appraisal. Population and Development Review, 19(3), 431466.

Massey, D. S., Axinn, W. G., \& Ghimire, D. J. (2010). Environment Change and Out-migration: Evidence from Nepal. Population and Envrionment, 32(2-3), 109-136.

Massey, S. D., \& Tourangeau, R. (2013, Jan). Introduction: New Challenges to Social Measurement. American Academy of Politcal and Social Science, 645(The Nonresponse Challenge to Surveys and Statistics ), 6-22.

Ministry of Agriculture Development. (2015). Monitoring, Evaluation, and Statistics Divison. Kathmandu: Government of Nepal.

Ortiz, R. (2012). Climate Change and Agricultural Production. Swedish University of Agriculture Sciences . Inter-American Development Bank.

Pidgeon, N., Kasperson, R. E., \& Slovic, P. (2003). The Social Amplification of Risk. New York: Cambridge University Press.

Poros, M. (2011, March 30). Migrant Social Networks: Vehicles for Migration, Integration, and Development. New York, United States.

Satyal, V. R. (2010). Agriculture in Decline. Economic Journal of Development, 11-12(1-2).

Smith, C., Kniveton, D., Wood, S., \& Black, R. (2017). Climate Change and Displacement. Forced Migration Review, 59.

Stark, O., \& Bloom, D. E. (1985). The New Economics of Labor Migration. The American Economic Review, 75(2), 173-178.

Tusneem, M. (n.d.). Food Security in a Changing Climate. The Pakistan Development Review, 47(4), 815-816

Van der Linden, S. (2017). Determinants and Measurement of Climate Change Risk Perception, Worry, and Concern. Cambridge: University of Cambridge. 
Wildavsky, A., \& Dake, K. (1990). Theories of Risk Perception: Who Fear What and Why? American Academy of Arts \& Sciences, 119(4), 41-60.

Williams, N. E. (2013, Nov). How Community Organizations Moderate the Effect of Armed Confliect on Migration in Nepal. Journal of Population Studies, 67(3), 353-369.

\section{Appendix}

Table 1. Measures of Environmental Change

\begin{tabular}{|c|c|c|c|}
\hline \multirow{4}{*}{$\begin{array}{l}\text { Change in agriculture } \\
\text { production }\end{array}$} & Increase & 35 & 32.7 \\
\hline & Decrease & 41 & 38.3 \\
\hline & No Change & 30 & 28 \\
\hline & Total & 106 & 100 \\
\hline \multirow{9}{*}{$\begin{array}{l}\text { Reasons for productivity } \\
\text { decrease }\end{array}$} & No irrigation facility & 37 & 23.3 \\
\hline & Excess water & 5 & 3.1 \\
\hline & Unfavorable weather & 25 & 15.7 \\
\hline & Insects and diseases & 23 & 14.5 \\
\hline & Not enough manure & 20 & 12.6 \\
\hline & Application of excess chemical fertilizer & 15 & 9.4 \\
\hline & Poor quality manure & 6 & 3.8 \\
\hline & Deterioration of soil quality & 28 & 17.6 \\
\hline & Total & 159 & 100 \\
\hline \multirow{8}{*}{$\begin{array}{l}\text { Reasons for productivity } \\
\text { increase }\end{array}$} & Use of new crop varieties & 18 & 15.3 \\
\hline & Better irrigation facilities & 23 & 19.5 \\
\hline & More favorable weather & 7 & 5.9 \\
\hline & Less insects and disease & 14 & 11.9 \\
\hline & Improved agricultural tools & 12 & 10.2 \\
\hline & Application of more manure & 25 & 21.2 \\
\hline & Application of more chemical fertilizers & 19 & 16.1 \\
\hline & Total & 118 & 100 \\
\hline
\end{tabular}


Table 2. Descriptive Statistics

\begin{tabular}{|c|c|c|c|c|c|}
\hline & $\mathrm{N}$ & Minimum & Maximum & Mean & Std. Deviation \\
\hline gender & 103 & 0 & 1 & 0.51 & 0.502 \\
\hline age & 100 & 19 & 81 & 44.24 & 14.577 \\
\hline caste & 92 & 1 & 5 & 1.85 & 1.342 \\
\hline Environment Change & $\mathrm{N}$ & Minimum & Maximum & Mean & Std. Deviation \\
\hline irrigration of Khet land & 102 & 0 & 1 & 0.90 & 0.299 \\
\hline Means of Irrigation & 97 & 1 & 3 & 1.54 & 0.646 \\
\hline $\begin{array}{l}\text { change in agriculture } \\
\text { production over the past } \\
\text { three year }\end{array}$ & 106 & 1 & 3 & 1.95 & 0.785 \\
\hline $\begin{array}{l}\text { change in amount of } \\
\text { chemical fertilizer }\end{array}$ & 77 & 1 & 3 & 2.09 & 0.814 \\
\hline difference in water table & 81 & 0 & 1 & 0.70 & 0.459 \\
\hline Environmental History & $\mathrm{N}$ & Minimum & Maximum & Mean & Std. Deviation \\
\hline moves due to drought & 106 & 0 & 1 & 0.03 & 0.167 \\
\hline crop loss due to drought & 41 & 0 & 1 & 0.56 & 0.502 \\
\hline moved due to flood & 102 & 0 & 1 & 0.08 & 0.270 \\
\hline crop loss due to flood & 51 & 0 & 1 & 0.37 & 0.488 \\
\hline Social Capital & $\mathrm{N}$ & Minimum & Maximum & Mean & Std. Deviation \\
\hline international/domestic & 59 & 0 & 1 & 0.73 & 0.448 \\
\hline $\begin{array}{l}\text { participation in program } \\
\text { or campaign }\end{array}$ & 49 & 0 & 1 & 0.63 & 0.487 \\
\hline
\end{tabular}


Table 3. Descriptives

\begin{tabular}{|c|c|c|c|c|c|c|c|c|c|}
\hline & & \multirow{2}{*}{$\mathrm{N}$} & \multirow[b]{2}{*}{ Mean } & \multirow[b]{2}{*}{$\begin{array}{l}\text { Std. } \\
\text { Dev. }\end{array}$} & \multirow[b]{2}{*}{$\begin{array}{l}\text { Std. } \\
\text { Error }\end{array}$} & \multicolumn{2}{|c|}{$\begin{array}{l}\text { 95\% Confidence } \\
\text { Interval for Mean }\end{array}$} & \multirow[b]{2}{*}{ Min. } & \multirow[b]{2}{*}{ Max. } \\
\hline & & & & & & $\begin{array}{l}\text { Lower } \\
\text { Bound }\end{array}$ & $\begin{array}{l}\text { Upper } \\
\text { Bound }\end{array}$ & & \\
\hline \multirow{3}{*}{$\begin{array}{l}\text { change in agriculture } \\
\text { production over the } \\
\text { past three year }\end{array}$} & No & 54 & 1.02 & 0.835 & 0.114 & 0.79 & 1.25 & 0 & 2 \\
\hline & Yes & 52 & 1.19 & 0.793 & 0.110 & 0.97 & 1.41 & 0 & 2 \\
\hline & Total & 106 & 1.10 & 0.816 & 0.079 & 0.95 & 1.26 & 0 & 2 \\
\hline \multirow[t]{3}{*}{ No irrigation facility } & No & 30 & 0.57 & 0.504 & 0.092 & 0.38 & 0.75 & 0 & 1 \\
\hline & Yes & 28 & 0.71 & 0.460 & 0.087 & 0.54 & 0.89 & 0 & 1 \\
\hline & Total & 58 & 0.64 & 0.485 & 0.064 & 0.51 & 0.77 & 0 & 1 \\
\hline \multirow[t]{3}{*}{ Excess water } & No & 31 & 0.10 & 0.301 & 0.054 & -0.01 & 0.21 & 0 & 1 \\
\hline & Yes & 28 & 0.07 & 0.262 & 0.050 & -0.03 & 0.17 & 0 & 1 \\
\hline & Total & 59 & 0.08 & 0.281 & 0.037 & 0.01 & 0.16 & 0 & 1 \\
\hline \multirow[t]{3}{*}{ Unfavorable weather } & No & 30 & 0.33 & 0.479 & 0.088 & 0.15 & 0.51 & 0 & 1 \\
\hline & Yes & 28 & 0.54 & 0.508 & 0.096 & 0.34 & 0.73 & 0 & 1 \\
\hline & Total & 58 & 0.43 & 0.500 & 0.066 & 0.30 & 0.56 & 0 & 1 \\
\hline \multirow[t]{3}{*}{ Insects and diseases } & No & 29 & 0.24 & 0.435 & 0.081 & 0.08 & 0.41 & 0 & 1 \\
\hline & Yes & 28 & 0.57 & 0.504 & 0.095 & 0.38 & 0.77 & 0 & 1 \\
\hline & Total & 57 & 0.40 & 0.495 & 0.066 & 0.27 & 0.53 & 0 & 1 \\
\hline \multirow[t]{3}{*}{ Not enough manure } & No & 30 & 0.40 & 0.498 & 0.091 & 0.21 & 0.59 & 0 & 1 \\
\hline & Yes & 31 & 0.26 & 0.445 & 0.080 & 0.09 & 0.42 & 0 & 1 \\
\hline & Total & 61 & 0.33 & 0.473 & 0.061 & 0.21 & 0.45 & 0 & 1 \\
\hline \multirow{3}{*}{$\begin{array}{l}\text { Application of excess } \\
\text { chemical fertilizer }\end{array}$} & No & 30 & 0.27 & 0.450 & 0.082 & 0.10 & 0.43 & 0 & 1 \\
\hline & Yes & 28 & 0.25 & 0.441 & 0.083 & 0.08 & 0.42 & 0 & 1 \\
\hline & Total & 58 & 0.26 & 0.442 & 0.058 & 0.14 & 0.37 & 0 & 1 \\
\hline \multirow[t]{3}{*}{ Poor quality manure } & No & 30 & 0.13 & 0.346 & 0.063 & 0.00 & 0.26 & 0 & 1 \\
\hline & Yes & 28 & 0.07 & 0.262 & 0.050 & -0.03 & 0.17 & 0 & 1 \\
\hline & Total & 58 & 0.10 & 0.307 & 0.040 & 0.02 & 0.18 & 0 & 1 \\
\hline \multirow{3}{*}{$\begin{array}{l}\text { Deterioration of soil } \\
\text { quality }\end{array}$} & No & 30 & 0.43 & 0.504 & 0.092 & 0.25 & 0.62 & 0 & 1 \\
\hline & Yes & 28 & 0.54 & 0.508 & 0.096 & 0.34 & 0.73 & 0 & 1 \\
\hline & Total & 58 & 0.48 & 0.504 & 0.066 & 0.35 & 0.62 & 0 & 1 \\
\hline \multirow{3}{*}{$\begin{array}{l}\text { use of chemical } \\
\text { fertilizer three years } \\
\text { ago }\end{array}$} & No & 51 & 0.82 & 0.385 & 0.054 & 0.72 & 0.93 & 0 & 1 \\
\hline & Yes & 49 & 0.88 & 0.331 & 0.047 & 0.78 & 0.97 & 0 & 1 \\
\hline & Total & 100 & 0.85 & 0.359 & 0.036 & 0.78 & 0.92 & 0 & 1 \\
\hline
\end{tabular}

